\title{
STUDIES ON THE INFLUENCE OF PRONIFER AS A PROBIOTIC ON THE CLINICAL, HEMATOLOGICAL AND BIOCHEMICAL STATUS OF GOAT'S KIDS (With 5 Tables)
}

$$
\text { By }
$$

(Received at 24/6/2003)

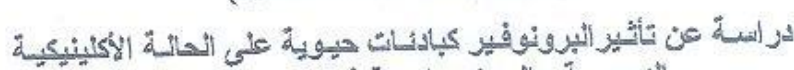

$$
\begin{aligned}
& \text { و } \\
& \text { the }
\end{aligned}
$$

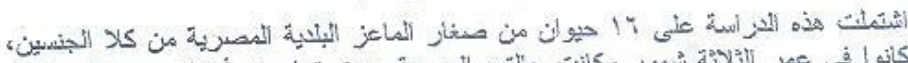

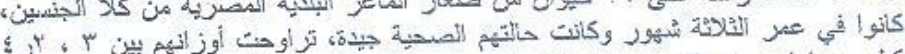

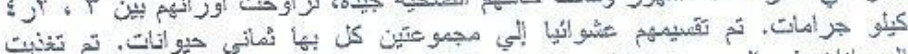

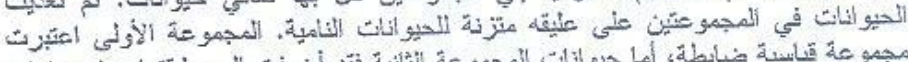

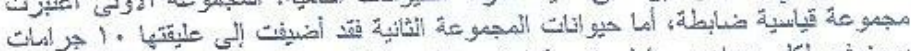

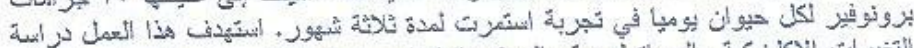

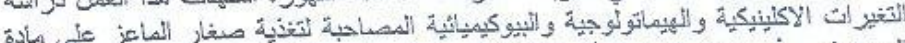

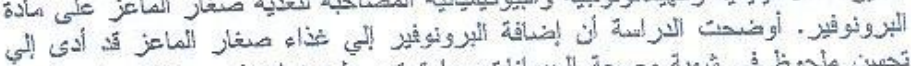

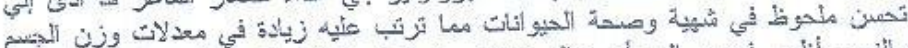

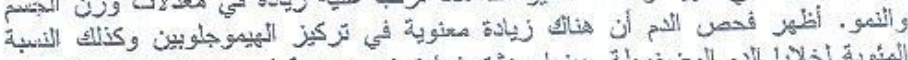

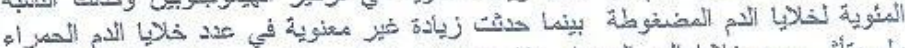

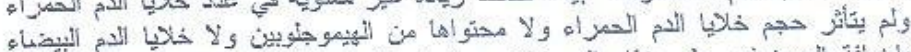

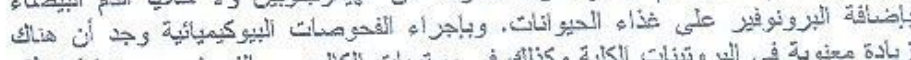

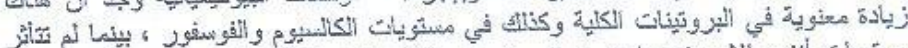

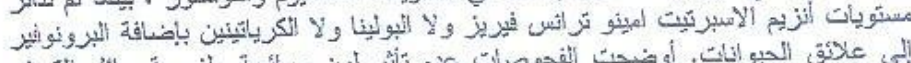

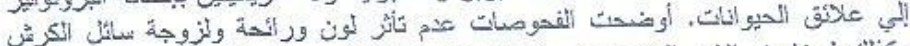

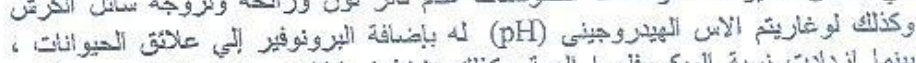

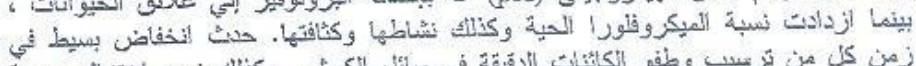

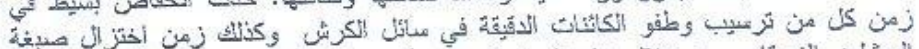

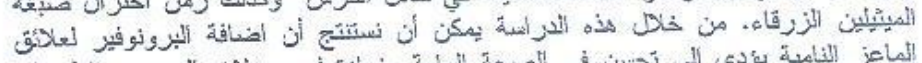

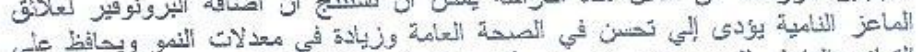

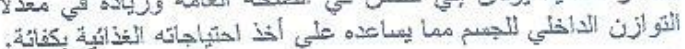




\section{SUMMARY}

A total number of 16 animals (Egyptian balady goat's kids) of both sexes were used in this study. These animals were three months old, of kids were rate and with an average body weight of $3-4.2 \mathrm{~kg}$. The kids were randomly divided into two groups, each of 8 animals. The according to NRC supplemented whe (1981). The diets of the second group were day, however the animals in a rate of 10 grams pronifer per animal/ and considered animals in the first group were fed pronifer free diets This work aimed to study the clini biochemical hol to study the clinical, hematological and some supplemented diets. Addition fing feeding of goat's kids on pronifer and health of the kids, their weight the kids, consequently resulted in significant increase in fed pronifer fed pronifer supplemented diets revealed significant increase in the insignificant concentration and hematocrit value associated with insignificant elevation in the total erythrocytic count and no alteration in corouscular hemoglar volume, mean corpuscular hemoglobin, mean biochemical study robin concentration and total leucocytic count. The of total protein, revealed significant increase in the blood serum levels other hand blood serum level pronifer, on the urea and creatinine were not altered aspartate aminotransferase (AST), samples of these animere not altered. Investigations of rumen fluid viscosity, odor and pH. There were insignificant alteration in the color, and percentage of ruminal micro fivity, density and percentage of ruminal micro flora in addition to slight reduction in rumen fluid rumen fluid samples of kids fed pronifer. It could be concluded that the their their health and performance, as it improves the density, function and retention of the rumen flora, improve blood picture and increase the retention of nitrogen and some minerals, consequently improve the body weight gain of growing kids. Normal internal homeostasis can be expected. Maintaining internal equilibrium will help the insurance that for growth.

Key words: Pronifer, probiotic, goat's kids. 


\section{INTRODCCTION}

Great attentions are oriented toward the use of probiotics in animal feeding for the improvement of the performance and the production. The term "probiotic" has been used to describe the growth promoting factors produced by microorganisms or substances which contribute to intestinal microbial balance (Parker, 1974). Probiotic is a mono or a mixed culture of living microorganisms applied to animal or man to improve the properties of the endogenous micro flora (Nahashors et al., 1992). Pronifer is one of those probiotics, which are composed mainly of Lactobacillus bacterial cocktail (Table 1) similar to those present in the animal gastrointestinal tract. Furthermore no residues of pronifer have been found in milk or meat of animals supplemented with it (Sadiek and Böhm, 2001).

Several functions of probiotics have been proposed including; the protection of young animals against enteropathic disorders, promoting feed conversion efficiency and increased live weight gain (Fuller, 1989 and Windschit1, 1992). Probiotic agents improve the balance of the intestinal micro flora, preventing diarrhea, increasing fat, nitrogen, calcium, phosphorus, copper and manganese retention resulting in improved animal health and increased animal growth rate (Sission, 1988 and Nahashon et al, 1992).

Many studies have demonstrated the positive influence of probiotics on animal health and performance (Böhm and Srour, 1995). The most positive effect of probiotics is expected in sub optimal hygienic measures in indoor animals, stresses, inferior feed quality, transport, heat or unfavorable weather and in parasitism. These conditions may be better managed by using probiotics (Games, 1987 and Sisson, 1988). It was reported that probiotics (Lactobacilli) were known to be potent immunostimulant that are directly activate macrophage function or indirectly interact with immunopotentiators. In ruminants changes in the feed eventually causes significant changes in microbial activity which in turn may affect the host (Hungate, 1957) Probiotics have a great significant importance in this aspect. Martin and Nisbet (1990) reported that probiotics stimulated the in vitro mixed rumen microorganism's fermentation of starch and amino acids. Furthermore several workers reported that addition of probiotics to animal feed or its use in vitro rumen fermentation increased the dry matter and protein digestion (Wiedmyer et al., 1987), increased fiber digestion (Games- 
Alarcon et al., 1990) and change rumen $\mathrm{pH}$ and volatile fatty acids (Martin and Nisbet, 1990 and Sadiek and Böhm, 2001).

More studies are needed in the aspect of the use of probiotics in the livestock feeding to be aware from any side effect on the animal health (Gillespie, 1987). The commercial use of probiotics in the last few years of sheep and goats is relatively now, only within the last few years research workers have documented the results of implenting probiotics into sheep and goats diets (Denev, 1993),

This study aimed to; 1 - Throw a light on the clinical status of addition to feed rations supplemented with pronifer (probiotic), in addition to monitoring the accompanied hematological and some gain of the changes. 2- Studying the effect of pronifer on the weight gain of the growing kids as well as its effect on their ruminal juice state.

\section{I- Animais (goat's kids):}

\section{MATERIALS and METHODS}

Total number of 16 Egyptian balady goat's kids of both sexes, 3 months old and with an average body weight of $3-4.2 \mathrm{~kg}$ were used in this study. The routine clinical examination and laboratory investigations including hematological analysis, liver and kidney function tests and healthy status. Whe carried out for each animal to ensure their good healthy status. The animals were randomly divided into two groups, each of 8 animals (control and experimental group). The animals of both groups were fed balanced growing ration for goats according to NRC (1981). The diets of the second group were supplemented with pronifer at a rate of 10 grams pronifer per animal / day, however the animals in the first group were fed pronifer free diets and considered as control. The furated for three months.

\section{II- Pronifer:}

Pronifer, produced by Egger GmbH, Mitterlabill, Austria was used (Table, 1). The recommended dosage is $1-3 \mathrm{~kg}$ per ton of finished 
Assiut Vet. Med. J. Vol. 49 No. 98. July 2003

Table 1: The chemical constituents of the product pronifer.

\begin{tabular}{|l|c|l|}
\hline \multicolumn{1}{|c|}{ Contents } & Amount \% & \multicolumn{1}{|c|}{ Bacterial population } \\
\hline Moisture & 11.0 & Lactic acid bacteria count $10^{6} \mathrm{CFU}$ \\
Crude protein & 43.0 & Organism /g product. \\
Crude fiber & 7.00 & \\
Ashes & 6.00 & Lactic acid bacteria spp. \\
$\mathrm{Ca}$ & 0.50 & L. plantarum \\
$\mathrm{P}$ & 0.70 & L.brevis \\
Lysine & 2.70 & L.casei \\
Methionine & 0.65 & L.fermentum \\
D-L Lactic acid & 9.00 & Pediococcous acidilactic \\
\hline
\end{tabular}

; Sadiek and Bơim (2001).

III- Samples and adopted methods:

A) Blood samples: two blood samples were collected at the end of the experiment from each animal of the two groups.

2-3 $\mathrm{ml}$ whole blood samples with anticoagulant disodium salts of EDTA were used for complete blood picture according to Coles (1986).

$8-10 \mathrm{ml}$ whole blood without anticoagulants, were collected for obtaining blood serum for the determination of total protein (T. ptn, $\mathrm{g} / \mathrm{L})$, Albumin (Alb., g/l), calcium (Ca, mmol/l), phosphorus $(\mathrm{P}$, mmol/1), aspartate aminotransferase (AST, u/l) urea, mmol/l and creatinine, $\mu \mathrm{mol} / 1$ by the using of test kits supplied by Boehringer Manheim $\mathrm{GmBH}$ diagnostica.

B) Ruminal Juice samples:

On the last day of the experiment ruminal Juice samples were collected in the morning from each animal of both groups by the use of stomach tube. The samples immediately transported to incubator at $37 \mathrm{C}$, physical, biochemical and microscopical examination of rumen fluid samples were carried out according to Rosenberger (1990).

\section{V-Statistical analysis:}

Statistical analysis of the obtained data were done by means of Soft ware computer program (SPSSWTN, 1995).

\section{RESULTS}

Clinical findings: The animals were examined clinically and clinical observations were daily recorded along the experimental period. 


\section{Assiut Vet. Med. J. Vol. 49 No. 98 , July 2003}

All kids fed pronifer supplemented diets showed improvements in their appetite (feed intake slightly increased specially at the $2^{\text {nd }}$ and $3^{\text {To }}$ months of feeding pronifer). The body weight (BW) and the body weight gain (BWG) were increased in comparison to control kids (Table, 2). No obvious signs were observed on kids fed either pronifer free diets or those supplemented with pronifer. Defecation, urination, internal body temperature, arterial pulse and respiration were normal. Skin and coats were lustrous and shining.

Hematological and biochemical findings: The total red blood cell count $(\mathrm{RBC}, \mathrm{T} / \mathrm{l})$, Hemoglobin $(\mathrm{Hb}, \mathrm{g} / \mathrm{l})$ packed cell volume ( $\mathrm{PCV}, \%)$ white blood cell count (WBC, G/1), mean corpuscular volume (MCV, fl), mean corpuscular hemoglobin (MCH, pg) and the mean corpuscular hemoglobin concentrations (MCHC, gm \%) are presented in Table 3.

Blood serum levels of total protein (T. ptn., g/L), Albumin, $g / l$, calcium (Ca, mmol/1), phosphorus ( $\mathrm{P}$, mmol/1), aspartate aminotransferase (AST, u/l) urea, $\mathrm{mmol} / \mathrm{l}$ and creatinine, umol/I are illustrated in Table 4.

Rumen fluid analysis: Physical, some biochemical and microscopical finding of the examined ruminal fluid samples of the studied animals are shown in Table 5 .

\section{DISCUSSION}

Pronifer as a probiotic is composed mainly of lactobacillus bacterial cocktail, similar to those present in the animal gastrointestinal tract. Its use as a supplement for feeds especially that offered for young growing animals where they have ill developed rumen, well improve the balance of their gastrointestinal micro flora (Parker, 1974 and Nahashon et al., 1992). Balanced alimentary tract bacterial population is of great importance for maintenance of digestive function. A well functioning digestive tract is very important for the conversion of feed and for growth. Exposure of animals to stress and application of oral antibacterial agents may upset such balance (Holtershinken et al, 1991; fuller, 1989 and Sadiek and Bohm, 2001). Supplementation of animals with probiotics proved to be beneficial in maintaining such equilibrium either through the competitive exclusion of pathogenic bacteria or by the antagonistic activity of it (kopency et al., 1989).

In the present stady, pronifer was given as a probiotic feed additive for the growing goat's kids. The kids showed improvement in the general health state (appetite was good, skin and coat were lustrous 
and shining, rumen activity and animal performance were improved) similar resuits were reported previously by Nahashon et al. (1992) and Sadick and Bohm (2001).

Regarding body weight and body weight gain, the addition of pronifer to the diet $(10 \mathrm{~g} / \mathrm{head} / \mathrm{day}$ for 3 months) improves the body weight gain by $6.51 \mathrm{~kg}$ compared to the control group $5.21 \mathrm{~kg}$ (Table 2). It is clearly seen that the woight gain was increased with the increase of the period during which pronifer was added to the diet (Table 2). Significant increase in weight gain with the addition of pronifer, may be due to increased intake of dry matter and protein in addition to fiber utilization as reported by Wiedmeier et al. (1987) and Gamez-Alarcon et al. (1990).

Martin and Nisbet (1990) suggested that probiotic suppiementation might influence the growth of rumen bacteria and nutrients synthesis. Possibly, the improvement in the growth of the animals may be due to the increased feed utilization and the reduced excretion of endogenous nitrogen (Stockland, 1993). In this aspect, lactic acid bacteria present in pronifer were able to prevent or inhibit the growth of any pathogens, which may be found or may enter by any way to the gut of the animal. This agreed with Chateau et al. (1993) in the action of lactobacillus on the pathogen that may be found. The author found that addition of pronifer to animal diets act against any pathogen that may gain entrance to the animal's gut. These eventually facilitate and improve the process of digestion and absorption of the essential nutrients giving rise to best-feed utilization by the animals. In addition, lactobacillus bacteria present in the pronifer suppress ammonia production in the intestine and consequently enhancing growth and improving animal health.

Hematological investigations (Table 3) revealed significant increase $(p<0.05)$ in hemoglobin concentration, percentage of packed cell volume and slight insignificant elevation in the total erythrocytic count of kids fed pronifer supplemented diets. On the other hand, mean corpuscular volume, mean corpuscular hemoglobin, mean corpuscular hemoglobin concentration and total leucocytes count were not affected in the animals of both groups. Concerning literature, the use of pronifer as feed additive in goats is rare, however Sadiek and Bohm (2001) reported insignificant alteration in the hemogram of sheep fed pronifer.

The biochemical stuciy (Table 4 ) revealed significant increase $(P$ $<0.01$ ) in the blood serum levels of total protein, calcium and phosphorus of kids fed pronifer, however the blood serum levels of the 
aspartate aminotransferase (AST), uree and creatinine were nearly tho same as those of the control group. The improved appetite, feec utilization and the nutritive value of pronifer may be considered the cause of the elevated protein calcium and phosphorus. Findings of normal values of AST, urea and creatinine revealed healthy liver and kidney and proved that pronifer has no side effect on the animal health, Nahashon et al. (1992), Bohm and Srour (1995) and Sadeik and Bohm (2001) reported similar results.

Investigations of rumen fluid samples (Table 5) revealed insignificant alteration in the color, viscosity, odor and $\mathrm{pH}$ of samples from pronifer fed animals and that of control one. On the other hand, there were a slight reduction in the sedimentation floatation and methyline blue reduction times and a slight increase in the a activity of the micro flora of ruminal fluid samples collected from kids fed pronifer. The sedimentation activity test provides a rapid evaluation of the microbial activity of the rumen and methyline blue reduction time is a semi quantitative estimation of redox potential, that reflect the anaerobic fermentative metabolism of bacterial population (Dirksen, 1969 and Rosenberger, 1990) The reduced sedimentation floatation time and methyline blue reduction time could be attributed to the positive effect of pronifer on the activity of ruminal flora and fauna. Sadiek and Bohm (2001) reported similar results.

It could be concluded that, the use of pronifer as a probiotic for growing kids will result in improvement of their health and performance, as it improves the density, function and activities of the rumen flora. It also improve blood picture, increase the retention of nitrogen and some minerals and consequently improve the body weight gain of growing kids. Normal internal homeostasis can be expected. Maintaining internal equilibrium will help the insurance that animals are supplied with the required sources of energy and nutrients for growth.

\section{REFERENCES}

Böhm, J, Srour, A. (1995): An Austrian probiotic feed additive. Soc. Cattle Dis., Assiut, Egypt, I: 185-188.

Chateau, N. Castellanos, I. And Deschamps, A.M. (1993): Distribution of pathogen inhibition in the bacillus isolates of a commercial probiotic consortium. Journal of Applied Bacteriology, 74: 3640. 
Coles, E.H. (1986): Veterinary clinical pathology $4^{\text {th }}$ Ed., Sounders company, Philadelphia, London, Toronto.

Denev, $S$. (1993): probiotics in lambs nutrition European commission, (sheep \& goat nutrition) 24-26 Sept.; 87.

Dirksen, G. (1969): $1^{\text {st }}$ die "Methylenblauprobe" als Schnelltest fur die klinische Pansensaftuntersuchung geeignet? Dtsch. Tierarztl. Wschr. 76, 305-309.

Fuller, R. (1989): Probiotics in man and animals. Journal of Applied Bacteriology, 66: 636-642.

Games, R.G. (1987): Animal Nutrition and Feeding. Text Book Demar Publisher INC USA.

Gamez-Alarcon, C.A.; Duda and Hebert, J. T. (1990): Influence of cultures of Aspergillus oryzae on rumen \& total digestibility of dietary components. J. Daily Sci, 72: 702-710.

Gillespie, J.R. (1987): Cell mediated immunity and nutritional balance, INC, USA.

Holtershinken, M., Scholz. H., Stober, M. (1991): Auswirkung oral zu verabreichender Therapeutika aut die Fermentationsvorgange im Pansensaft ruminierender Rinder. 3. Mitt: Baquiloprim/ Sulfadimidin (in vitro). Tierarztl. Umschau 46: 265-268.

Hungate, R.E. (1957): Microorganisms in the rumen of cattle fed a constant Ration. Can. J. Microb.

Kopency, J., Simunek, J., Kalacinjuk, G.L., Savka, O.G., Gerasimov, M. G., Leskovic, B. (1989): Testing the probiotic effect of selected rumen bacteria. Zivocisna-Vyroba 34, 205-209.

Martin, S.A. and Nisbet, D. J. (1990): Effect of Aspergillus oryzae fermentation extract on fermentation of amino acids, bermudagrass \& starch by mixed ruminal microorganisms in vitra. J. Anim. Sci. 68: 2142-2149,

Nahashon, S.N., Nakuaue, H.S., Mirosh, L.W. (1992): Effect of direct fed Microbial on nutrition retention and production parameters of laying pullets. Poultry Sci. 7 ! (Supp1. 1), 111-115.

NRC (1981): Nutrient requirements of domestic animals, No.15 Nutrient Requirements of Goats in temperate and tropical countries. National Academy press, Washington, D.C.

Parker, R.B. (1974): Probiotics - the other half of the antibiotic story. Anim. Nutrit. Health 29, 4-9.

Rosenberger, G. (1990): Die klinische Untersuchung des Rindes. 3. Aufl., Parey, Berlin, S. 670-677. 
Sadiek, A.H. and Böhm, J. (2001): Influence of Pronifer as aprobiotic on the rumen fluid and blood parameters of sheep fed different roughage concentrate based diets. Wiener Tierarztliche
Monatscshrift, 88: $4-10$.

Sission, J.W. (1988): Potential of probiotics organism to prevent diars hoea and promote digestion in farm animals. J. Food Agric. Sci., 49: 1-13.

Stockland, W. (1993): Effect of yeast culture on reproductive performance of gills over two cycles \& performance of their piglets. European lecture tour. 87-94.

SPSSWIN (1995): Software programe for statistical analysis under windows- USA.

Wiedmeier, R.D.; Arambel, M.J. and Walters, J.L. (1987): Effect of yeast culture and Aspergillies oryzae fermentation extract on 70:2063-2068.

Windschitl, P.M. (1992): Effects of probiotic supplementation of hulless barley and corn-based diets on bacterial fermentation in continuous culture of ruminal contents. Can. J. Anim. Sci. 72, 265-271. 


\section{Assiut Vet. Med. J. Vol. 49 No. 98. July 2003}

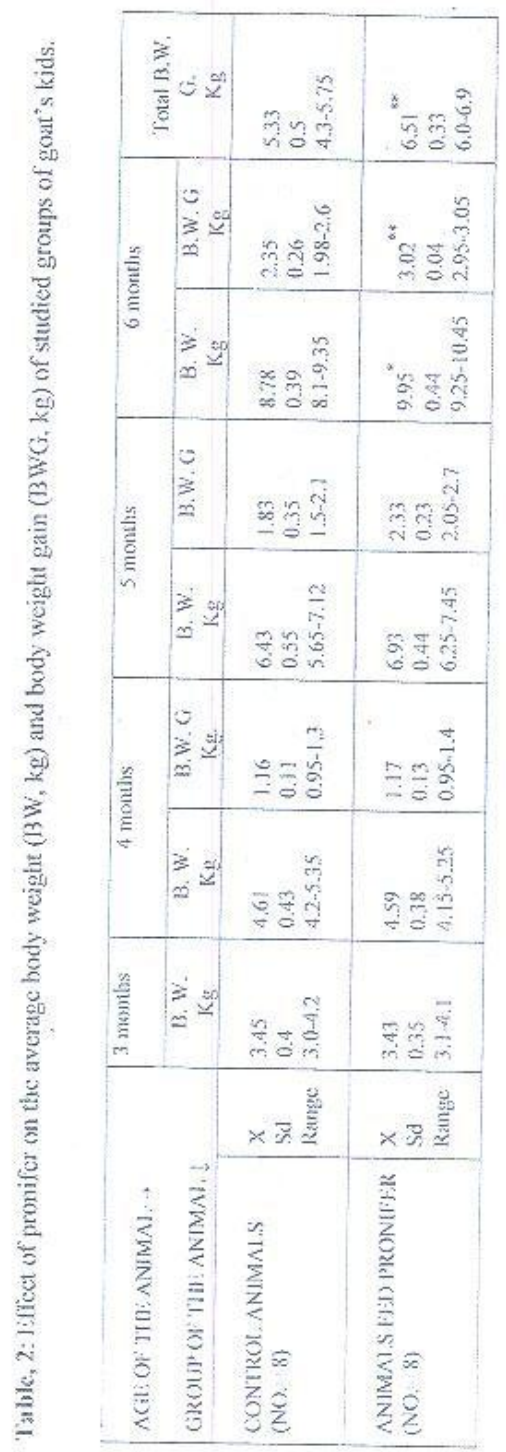


Table, 3: Mean ( $\mathrm{x}$ ) and standard deviation (Sd) values of blood picture of Studied groups of gost:'s kids.

\begin{tabular}{|c|c|c|c|c|c|c|c|c|}
\hline \multirow{2}{*}{\multicolumn{2}{|c|}{$\begin{array}{l}\text { PARAMETERS } \\
\rightarrow \\
\text { GROUP } \downarrow\end{array}$}} & \multirow{3}{*}{$\begin{array}{c}\mathrm{RBC} \\
\mathrm{TA}\end{array}$} & \multirow{3}{*}{$\begin{array}{l}\mathrm{Hb} \\
\mathrm{g} / \mathrm{I}\end{array}$} & \multirow{3}{*}{$\begin{array}{c}\mathrm{PCV} \\
\% \\
31.77\end{array}$} & \multirow{2}{*}{$\begin{array}{c}\text { WBC } \\
\text { Gil }\end{array}$} & \multirow{2}{*}{$\begin{array}{c}\mathrm{MCV} \\
\mathrm{Fi}\end{array}$} & \multirow{2}{*}{$\begin{array}{c}\mathrm{MCH} \\
\mathrm{Pg}\end{array}$} & \multirow{2}{*}{$\begin{array}{c}\mathrm{MCHC} \\
\mathrm{G} / \mathrm{d} !\end{array}$} \\
\hline & & & & & & & & \\
\hline $\begin{array}{l}\text { CONTROL } \\
\text { KIDS } \\
(N O=8)\end{array}$ & $\begin{array}{l}\mathrm{X} \\
\mathrm{Sd}\end{array}$ & & & & $\begin{array}{l}12.82 \\
3.01\end{array}$ & $\begin{array}{l}24.90 \\
4.34\end{array}$ & $\begin{array}{l}8.38 \\
1.39\end{array}$ & 33.91 \\
\hline $\begin{array}{l}\text { PRONIFER } \\
\text { FED KIDS } \\
(\text { NO. }=8)\end{array}$ & $\begin{array}{l}x \\
\text { Sd }\end{array}$ & $\begin{array}{c}14.49^{n .8} \\
2.65\end{array}$ & $\begin{array}{c}123.54^{\circ "} \\
12.37\end{array}$ & $\begin{array}{l}34.69^{\circ} \\
3.01\end{array}$ & $\begin{array}{c}11.34^{\text {n.s. }} \\
2.21\end{array}$ & $\begin{array}{c}24.92^{11.5} \\
3.46\end{array}$ & $\begin{array}{c}8.67^{n .5 .} \\
0.89\end{array}$ & $35.70^{\text {n.s. }}$ \\
\hline
\end{tabular}

Table 4: Mean (x) and standard deviation (Sd) values of blood serum, total protein (T. ptn), albumin (Alb.), calcium (Ca), phosphorus (P), aspartate aminotransferase (AST), urea and creatinine of studied groups of goat kids.

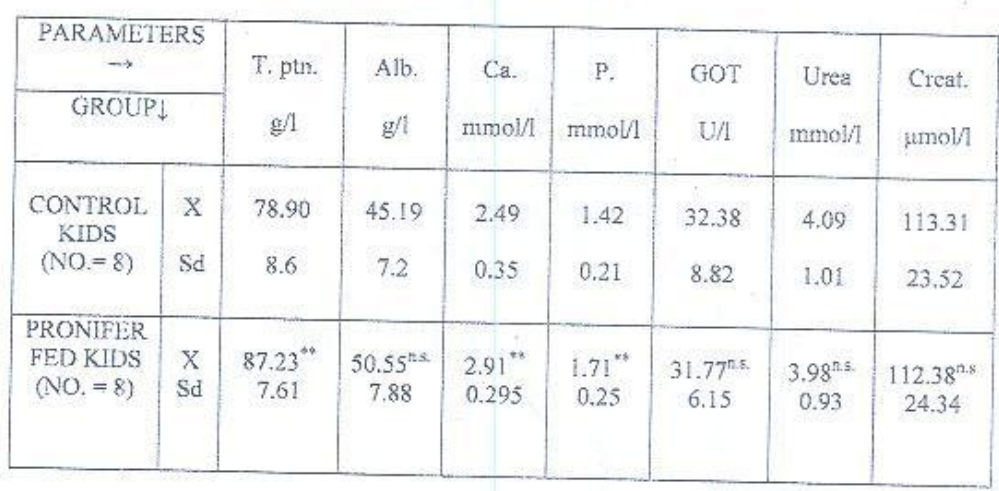


Assiut Vet. Med.J. Vol. 49 No. 98, July 2003

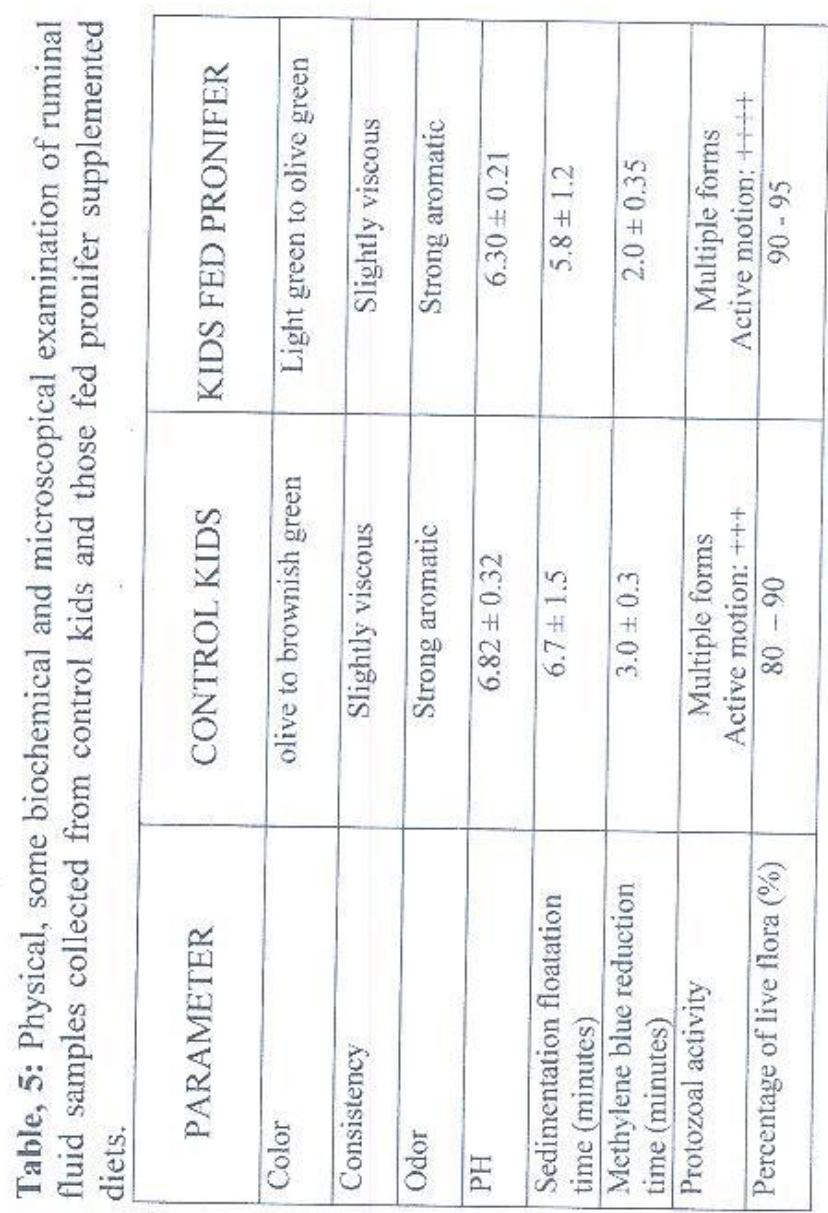

